\title{
59. DEEP SEA DRILLING PROJECT LEG 93: BIOSTRATIGRAPHIC SYNTHESIS ${ }^{1}$
}

\author{
Michel Moullade, Laboratoire de Micropaléontologie et de Géologie Marines, Université de Nice²
}

\section{INTRODUCTION}

The purpose of this synthesis paper is to summarize and to correlate the biostratigraphic information compiled from paleontological contribution to the Leg 93 Initial Reports. The basic data include the vertical distribution of four main groups of microfossils-foraminifers, nannofossils, radiolarians, and palynomorphs (mostly dinoflagellates)-from DSDP Sites 603, 604, and 605 (northwest Atlantic). When available, magnetostratigraphic data are included for correlation. Chronostratigraphic interpretations are then proposed for each epoch and are briefly discussed. Figures 1, 3, 4, and 5 integrate into the chronostratigraphic scheme the biozones and main biohorizons (datums), magnetozones and magnetic reversals, and boundaries of lithologic units for the Mesozoic and the Cenozoic-Quaternary sections drilled at Site 603, the Neogene-Quaternary sections at Site 604 , and the Upper Cretaceous-Paleogene sections at Site 605.

\section{MESOZOIC}

\section{Site 603 (Fig. 1)}

The chronostratigraphic interpretation of the Mesozoic sedimentary column drilled in Hole 603B is affected by several uncertainties that result chiefly from sedimentary disturbances (Neocomian turbidites, condensed mid-Cretaceous section), strong dissolution of calcareous microfossils (mainly foraminifers), and calibration problems (nannofossils and especially dinoflagellates).

When compiling the present Cretaceous synthesis I used the works of Thierstein $(1971,1976)$, Perch-Nielsen (1979), Manivit (1979), and Roth (1983) for calibrating the Lower Cretaceous nannofossil zonal schemes, and published (De Renéville and Raynaud, 1981; Habib and Drugg, 1983) or unpublished (Raynaud, pers. comm., 1985) results for examining the significance of the vertical distribution of $\mathrm{Ne}$ ocomian-Barremian dinoflagellates.

The studies of Manivit (1979) and Raynaud (in De Renéville and Raynaud, 1981, and unpublished data) are of particular interest, for they were carried out in the continuous, expanded, and macrofossiliferous sections that out crop in the Valanginian-Hauterivian hypostratotypic and Barremian type-locality areas (Angles, Vergons, Barret-le-Bas, southeast France). These works in-

\footnotetext{
${ }^{1}$ van Hinte, J. E., Wise, S. W., Jr., et al., Init. Repts DSDP, 93; Washington (U.S. Govt. Printing Office)

2 Address: Laboratoire de Micropaléontologie et de Géologie Marines, Universite de Nice, Parc Valrose, 06034 Nice Cedex, France.
}

clude precise and direct calibrations, bed after bed, of microfossil datums (foraminifers, ostracodes, nannofossils, dinoflagellates, etc). with the distribution of zonal ammonites. A summary of the main biostratigraphic and chronostratigraphic subdivisions and events is given for the Valanginian (and contacts) in Figure 2. Comparing this standard with the data obtained at Site 603, it is apparent that the base of Hole 603B cannot be older than early Valanginian. More precisely, the lowermost recovered Core 603B-82 is attributed to the basal Valanginian (Otopeta Zone), very close to (but just above) the Berriasian/Valanginian boundary, as defined in the hypostratotypic reference section (Busnardo et al., 1979).

As a result of this age assignment, the interpretation of the lower part of the magnetostratigraphic sequence for Hole 603B (Ogg, this volume), reported in Figure 1, becomes easier and clearer. The lowest observed magnetic anomaly can be attributed to M12n and correlates with the NC2/NC3 nannofossil zonal boundary, the top of the dinoflagellate Biorbifera johnewingi Zone, and the top of the ammonite Otopeta Zone. Such a correlation suggests an age of $137 \mathrm{Ma}$ for Section 603B-82-5 (the lowest section in the hole), using the Harland et al. (1982) time scale, in which the Berriasian/Valanginian boundary is fixed at $138 \mathrm{Ma}$.

For defining the Valanginian/Hauterivian boundary $(=131 \mathrm{Ma})$ in Hole 603B, I used the last appearance datum of the nannofossil species Cyclagelosphaera deflandrei (corresponding to the $\mathrm{NC} 3 / \mathrm{NC} 4$ zonal boundary; Roth, 1983). The highest occurrence of this marker is observed at the top of Core 603B-66. The resulting boundary coincides approximately with the upper portion of the M10n magnetic anomaly, which is easy to identify in Hole 603B on the basis of Ogg's measurements (this volume) and which also corresponds to the stage boundary in the Harland et al. (1982) scale.

The remaining upper part (i.e., above M10n) of the magnetostratigraphic column constructed for the Lower Cretaceous of Hole 603B cannot be sequenced in such a way as to compare with the standard M-sequence. (For an alternative explanation of the Hauterivian-Aptian magnetochronology of Hole 603B, see Ogg, this volume.)

On the basis of the lowest occurrence of the planktonic foraminiferal species Hedbergella sigali (Core 603B-61), the highest occurrence of the nannofossil species Cruciellipsis cuvillieri (603B-59) and Speetonia colligata (603B55 ), and the lowest occurrence of the dinoflagellate Odontochitina operculata (603B-60), the Hauterivian/Barremian boundary can be located at the base of Core 603B- 


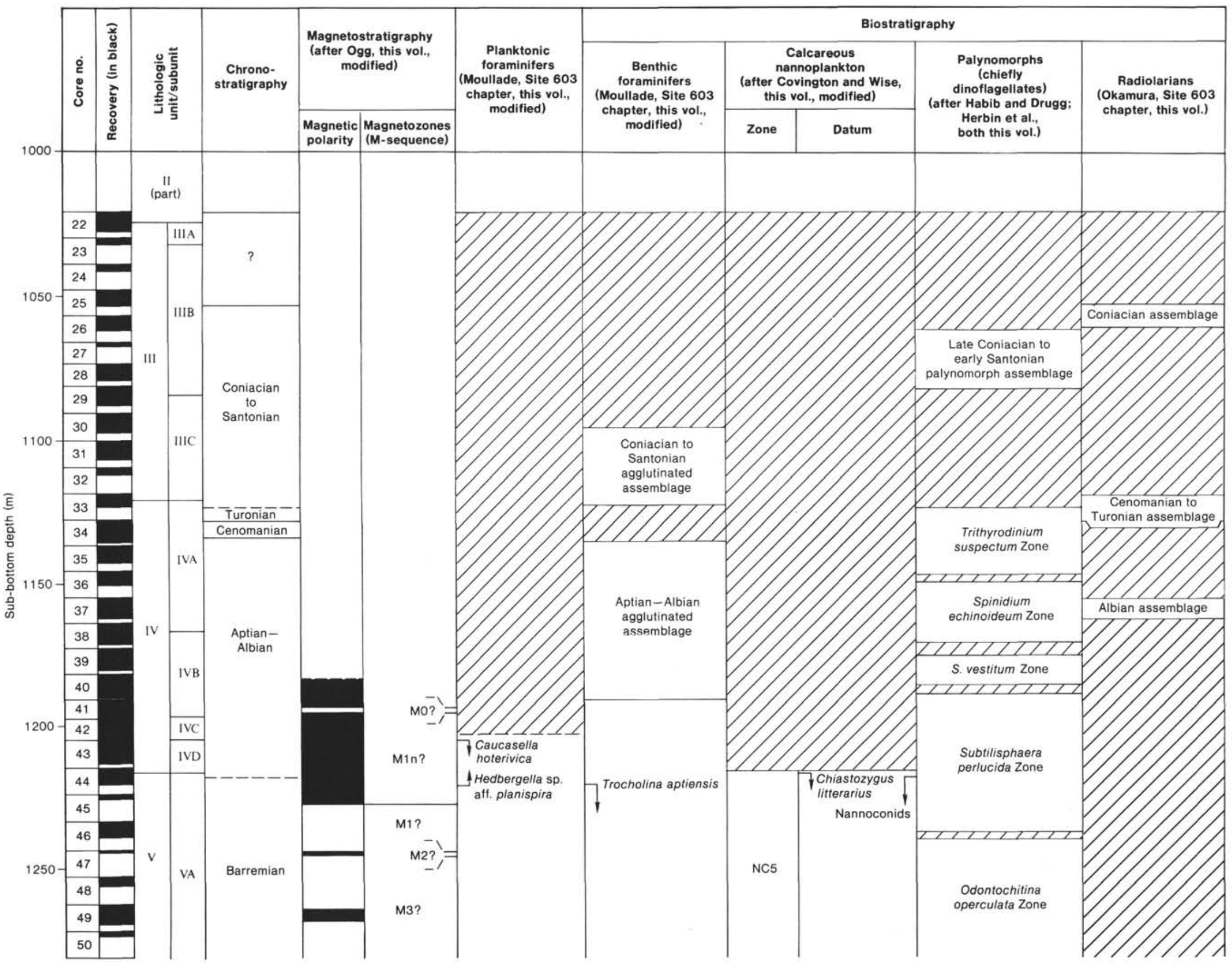




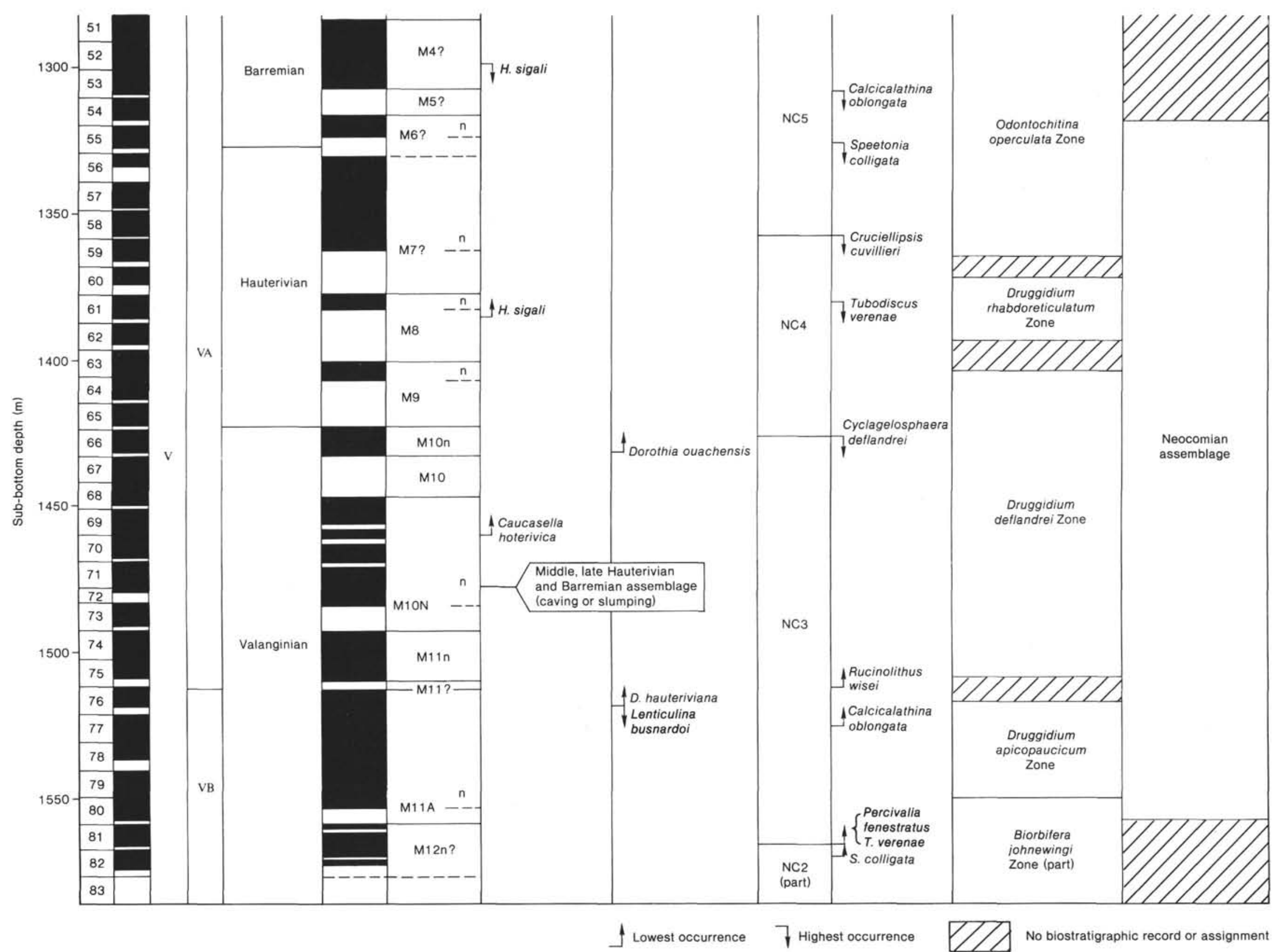




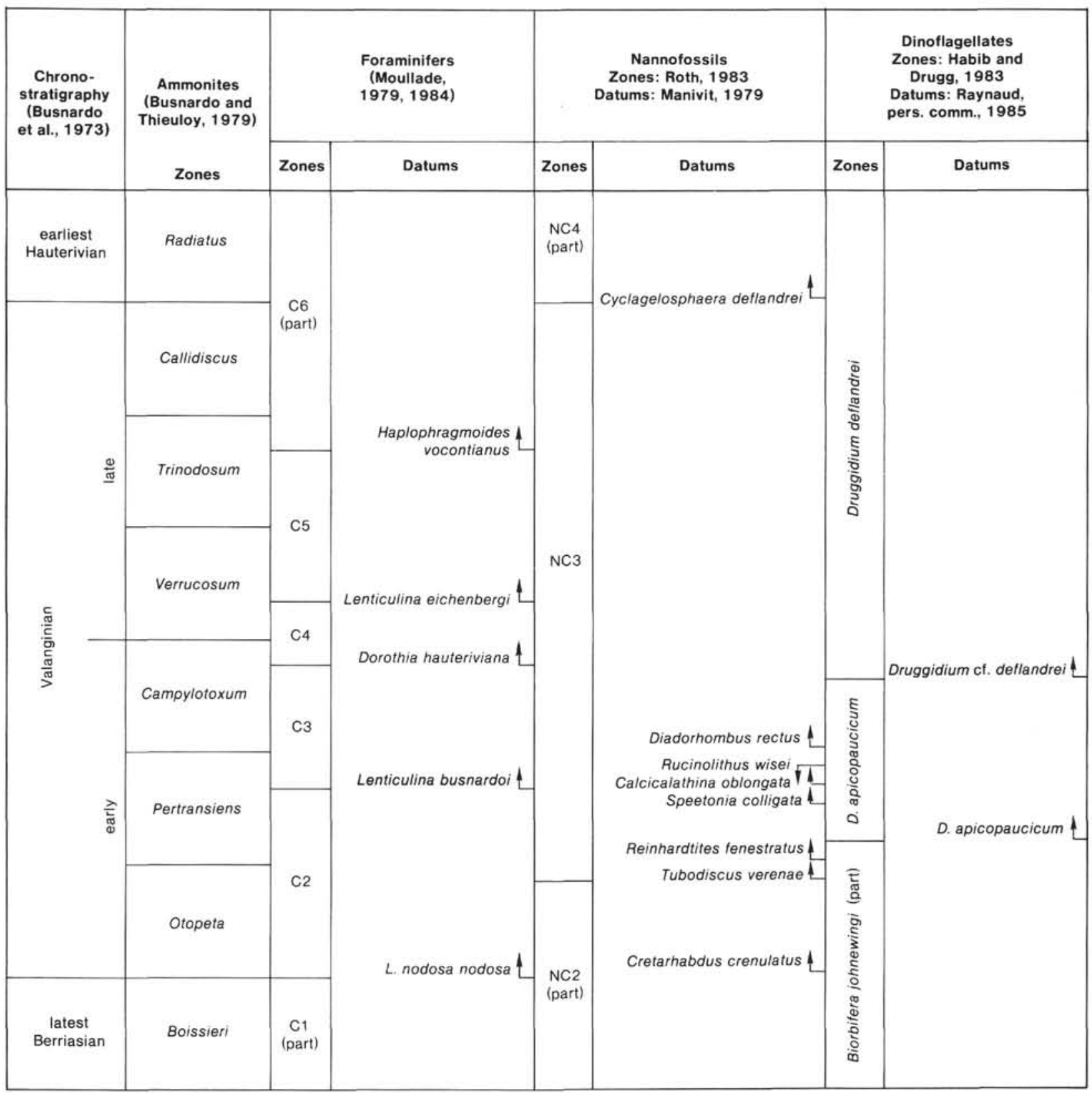

Figure 2. Chronostratigraphic assignment of Valanginian ammonite and microfossil zonal schemes and datums (southeastern France, Tethyan hypostratotypic area).

55. This assignment implies an important decrease in sediment accumulation rate during the lower Barremian interval, if one assumes that the highest occurrence of the nannofossil species Calcicalathina oblongata defines the lower/upper Barremian boundary (Thierstein, 1971). Based on this assumption, Cores 603B-55 and -54 represent a condensed lower Barremian section.

Such a condensation during the early Barremian could explain the obscure magnetostratigraphic pattern obtained for this interval.

The Barremian/Aptian boundary is tentatively defined in the upper part of Core 603B-44, mainly on the basis of the lowest occurrence of the planktonic foraminifer
H. sp. aff. planispira (Sample 603B-44, CC), which first appears in the latest Barremian (Moullade, 1966, 1974), and the highest occurrence of the dinoflagellate Druggidium deflandrei (Sample 603B-43-4, 63-65 cm), which last appears in the earliest Bedoulian in the Barremian stratotype according to De Renéville and Raynaud (1981). Such an interpretation is also consistent with the highest occurrence level of the planktonic foraminifer Caucasella hoterivica (Sample 603B-42, CC), the LAD (=last appearance datum) of which is early Aptian (Gradstein and Sheridan, 1983). These data do not support the proposition of Habib and Drugg (this volume) that the Barremian/Aptian boundary lies in Core 603B-47. (See also 
discussion by Wise and van Hinte, this volume.) This assumption does not seem to take into account the results obtained by De Renéville and Raynaud (1981).

The mid-Cretaceous interval cannot be precisely dated in Hole 603B by the foraminiferal record, and the entire post-Barremian sequence is essentially devoid of nannofossils. By joining poor foraminiferal and radiolarian information to slightly more precise data based on the dinoflagellate distribution (Habib and Drugg, this volume; Herbin et al., this volume) we can assign most of lithologic Unit IV an Aptian-Albian age. The Albian/ Cenomanian boundary is identified in Section 603B-345 by Herbin et al. Habib and Drugg point out that the Aptian/Albian boundary is in the upper part of Core 603B-43. This would imply a very important period of sedimentary condensation during the Aptian, confined to the upper part of Core 603B-44 and the lower part of Core 603B-43.

Another even more pronounced period of condensation appears to correspond to the Cenomanian-Turonian interval, contained in the upper part of Core 603B-34 and the bottom of Core 33, according to Herbin et al. (this volume) - an assignment also supported by radiolarian data.

The interval comprising the uppermost beds of lithologic Unit IV and the lower two thirds of lithologic Unit III contains a Coniacian to Santonian agglutinated benthic foraminiferal assemblage in the lower part, a late Coniacian to early Santonian dinoflagellate assemblage in the middle part, and a Coniacian radiolarian assemblage in the upper part; thus it is assigned a Coniacian to Santonian age. The upper part of lithologic Unit III cannot be precisely dated (see discussion later, in the $\mathrm{Pa}$ leogene section).

\section{Site 605 (Fig. 3)}

The deepest part of Hole 605 is composed of latest Cretaceous beds, $57 \mathrm{~m}$ thick, that can be more precisely attributed to the middle-late Maestrichtian on the basis of their foraminiferal, nannofossil, and dinoflagellate content. The corresponding magnetostratigraphic record (Bruins et al., this volume) shows that at this level at least Chrons 30 and 31 are represented, though the pattern does not appear totally clear. Part of Chron 32 (= earlymiddle Maestrichtian, cf. Lowrie and Alvarez, 1981) might also be present-an interpretation which leads to an estimated age of 70-71 Ma for the bottom of Hole 605 (Core 605-71).

The Cretaceous/Tertiary boundary occurs in Section 605-66-1, but cannot be strictly located, for the critical contact interval is brecciated. This explains how Sample 605-66-1, 73-74 cm yields lowermost Danian ( $\mathrm{P}_{\mathrm{O}}$ Zone) foraminifers, whereas Sample 605-66-1, $71 \mathrm{~cm}$ contains Maestrichtian nannofossils (Site 605 report, this volume).

\section{PALEOGENE}

\section{Site 603 (Fig. 4)}

Upper Paleocene to lower Eocene beds (comprising part of Core 603B-15 to Core 603B-21, lithologic Unit II) were penetrated in Hole 603B. Their age is based only on radiolarians, the vertical distribution of which indicates the presence of the Bekoma campechensis, B. bidartensis, Buryella clinata and Phormocyrtis striata striata zones (Site 603 chapter, this volume). As a result, the age of the underlying upper part of lithologic Unit III (entirely devoid of significant microfossils) lies between Santonian (see above) and Paleocene.

\section{Site 605 (Fig. 3)}

A 560-m-thick Paleocene to lower middle Eocene sequence was drilled in Hole 605. The Paleocene part is well dated by foraminifers (Saint-Marc, this volume), nannofossils (Lang and Wise, this volume), paleomagnetic measurements (Bruins et al., this volume). The Danian, Thanetian, Ypresian, and Lutetian stages have been identified. Sedimentation appears to be condensed during the Danian and, in contrast, highly expanded during the three younger stages.

The Danian/Thanetian boundary is established in Section 605-63-5, on the basis of the nannofossil (=CP2/ CP3 zonal boundary) and magnetostratigraphic (lowermost part of Chron 26) records. The nannofossil data also leads one to suspect that a hiatus may occur at this level (CP3 Zone).

The Thanetian (Paleocene)/Ypresian (Eocene) boundary is located in Section 605-44-5 on the basis of the foraminiferal data ( $=$ boundary between $\mathrm{P} 6 \mathrm{a}$ and $\mathrm{P} 6 \mathrm{~b}$ subzones) and in Section 605-44-1 on the basis of nannofossils (= boundary between CP8 and CP9 zones). There is a minor discrepancy of less that $6 \mathrm{~m}$ between these two microfossil stratigraphies.

The Eocene part of the sequence is better dated by nannofossils than by the very poorly preserved foraminifers; some sporadic biostratigraphic information is also given by radiolarians but unfortunately, no further magnetostratigraphic control is available above Chron 25 (late Thanetian). Nannofossil Zones CP9 to CP13 (in part; Subzone CP13C is missing) are all precisely delineated. The Ypresian/Lutetian boundary, which corresponds to the CP11/CP12 zonal boundary, is located in Section 605-31-5 (Applegate and Wise, this volume). The top of the Eocene part of the Hole 605 section, truncated by erosion and directly overlain by Quaternary beds, is thought to be no older than Lutetian (CP13b, Chiasmolithus gigas nannofossil Subzone; CP13c is not present; Applegate and Wise, this volume).

\section{NEOGENE-QUATERNARY}

\section{Site 603 (Fig. 4)}

A sequence about $600 \mathrm{~m}$ thick, presumably entirely Miocene, lies disconformably over lower Eocene beds at Site 603. Its lowest part (Core 603B-14 and the upper part of Core 603B-15) is devoid of nannofossils or radiolarians and contains only non age-diagnostic "Rhabdammina-like" agglutinated benthic foraminifers and early to middle Miocene fish teeth (Hart, this volume). Above this poorly dated basal interval, middle to late Miocene radiolarians, nannofossils, and planktonic foraminifers are unequally distributed. Because recovery of index fossils was poor, the middle/late Miocene boundary is hard to 


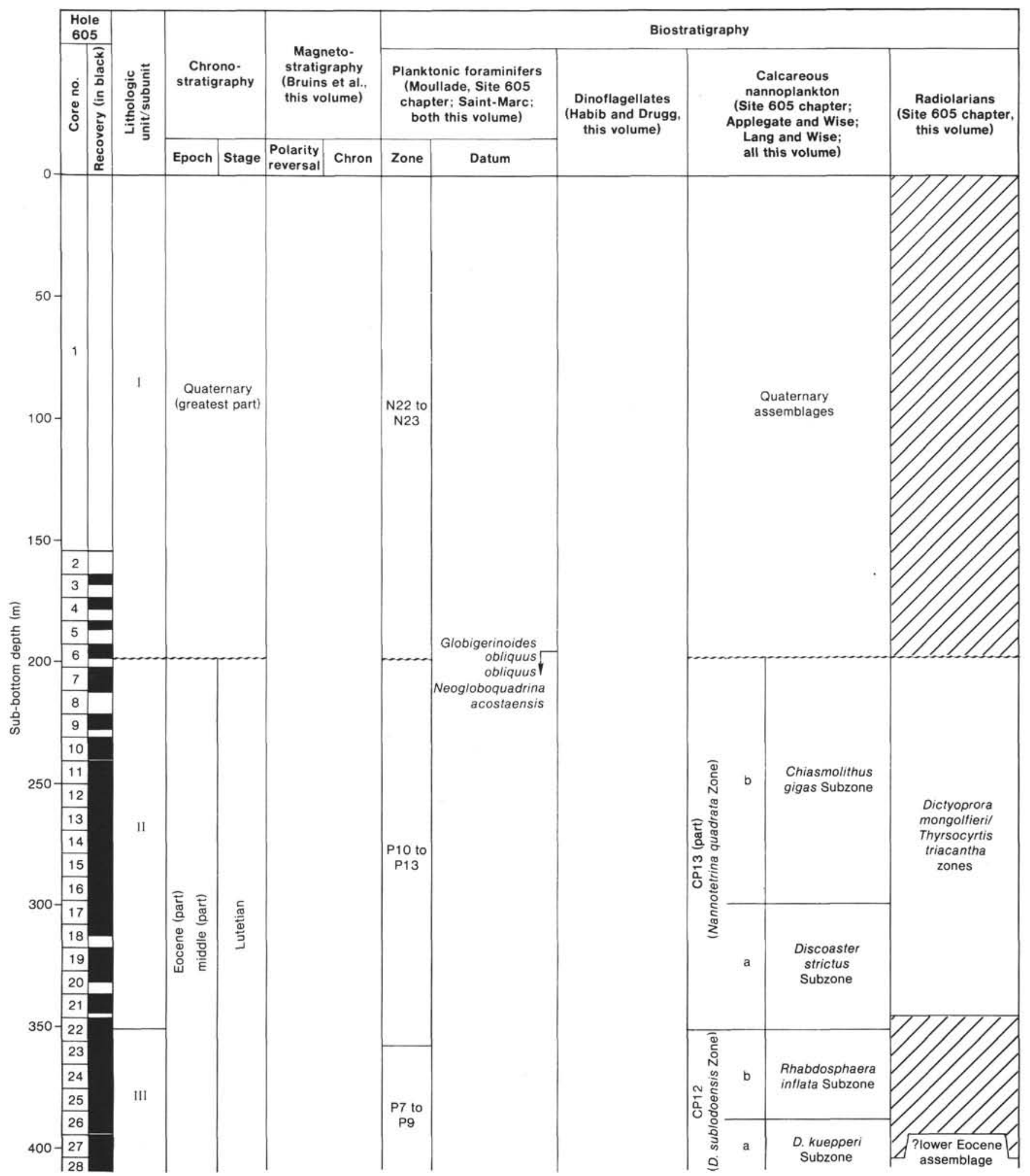

Figure 3. Late Cretaceous-Paleogene chronostratigraphy, magnetostratigraphy, and biostratigraphy, DSDP Site 605. For explanation of symbols, see Fig. 1.

precisely delineate and is somewhat arbitrarily fixed in Core 603-32, in which the planktonic foraminifer Neogloboquadrina acostaensis first occurs (Gervais, this volume).

Defining the Miocene/Pliocene boundary at Site 603 constitutes another problem. The best late Neogene stra- tigraphy can be established in the continuously cored Hole $603 \mathrm{C}$, and some discontinuous additional information can also be obtained from Hole 603 , in which rotary cores were taken approximately every $50 \mathrm{~m}$. On the basis of the nannofossil vertical distribution, the Miocene/ 


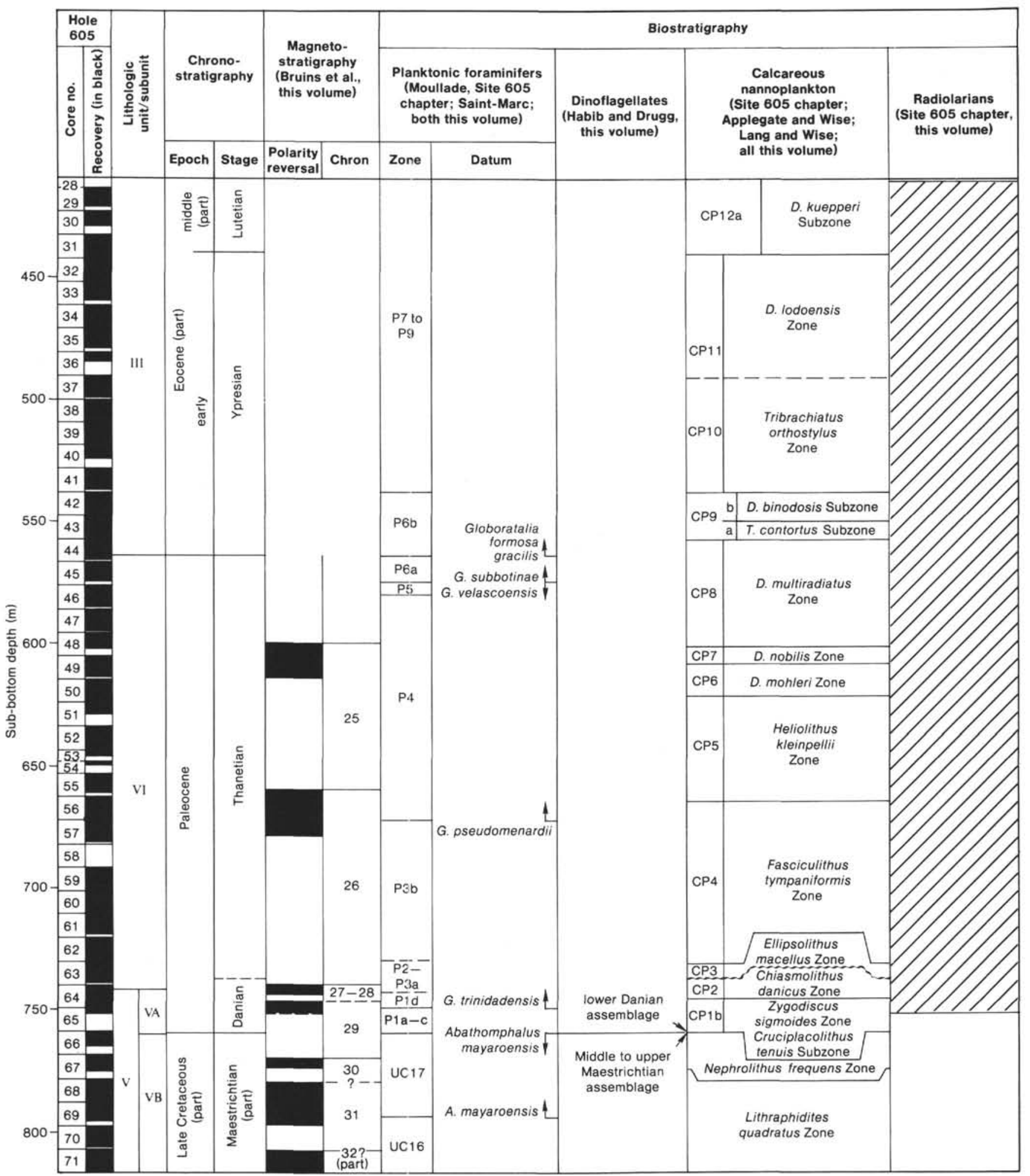

Figure 3 (continued).

Pliocene boundary should occur between Cores 603C-34 and -35 , at a sub-bottom depth of $310 \mathrm{~m}$ (= boundary between $\mathrm{CN} 10 \mathrm{a}$ and $\mathrm{CN} 10 \mathrm{~b}$ subzones; cf. Okada and Bukry, 1980). Neogene magnetostratigraphic data obtained for Hole 603C (Canninga et al., this volume) indicate that this hole would bottom in Chron 3, the deepest nor- mal-polarity interval of which spans Cores $603 C-33,-34$, and -35 (upper part). The underlying cored interval, although paleomagnetically not so clear, seems to be dominantly of reverse polarity and thus may be attributed to the reverse basal interval of Chron 3. This indicates that the uppermost normal-polarity interval of Chron $3 \mathrm{~A}$ was 


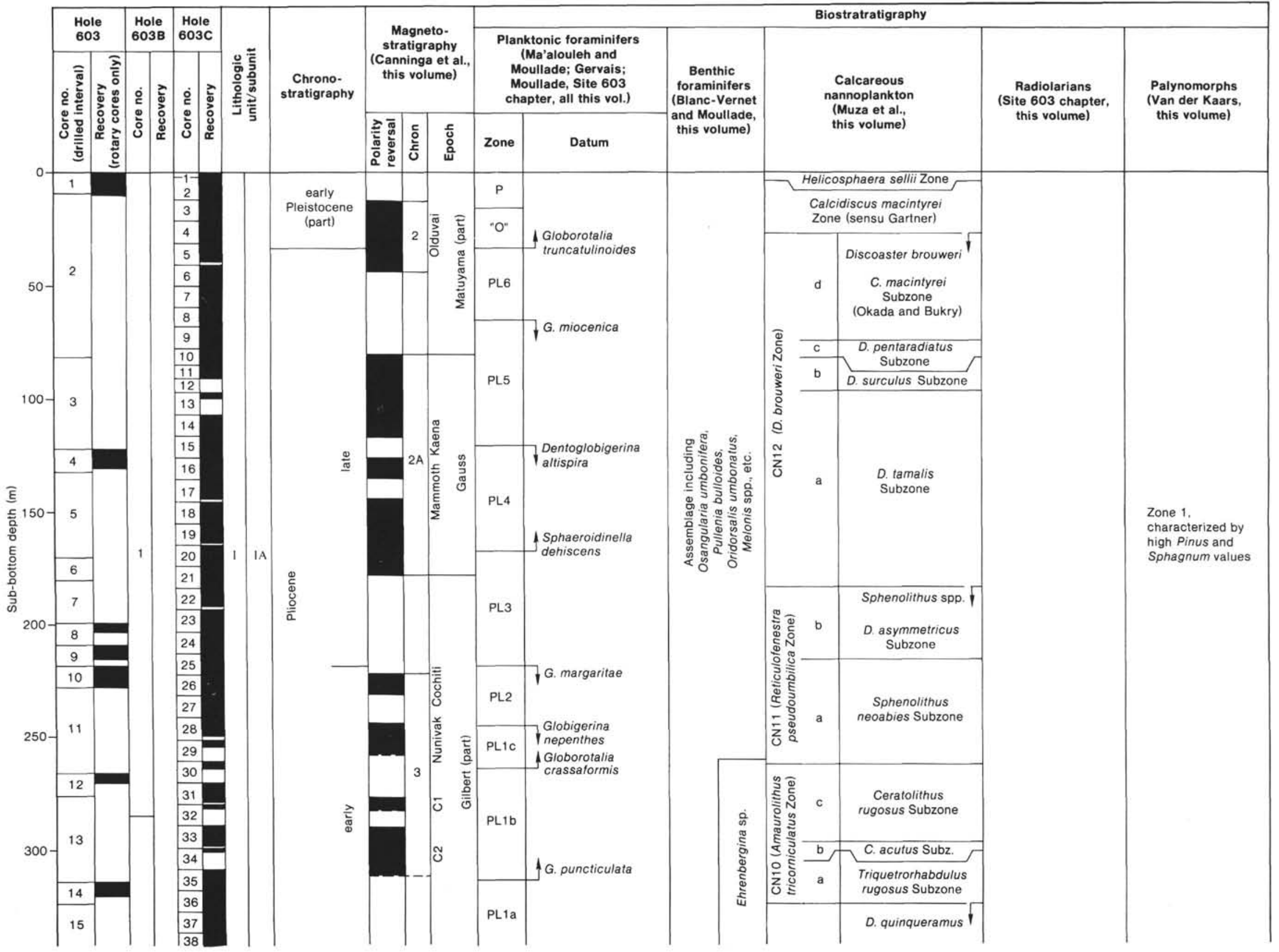




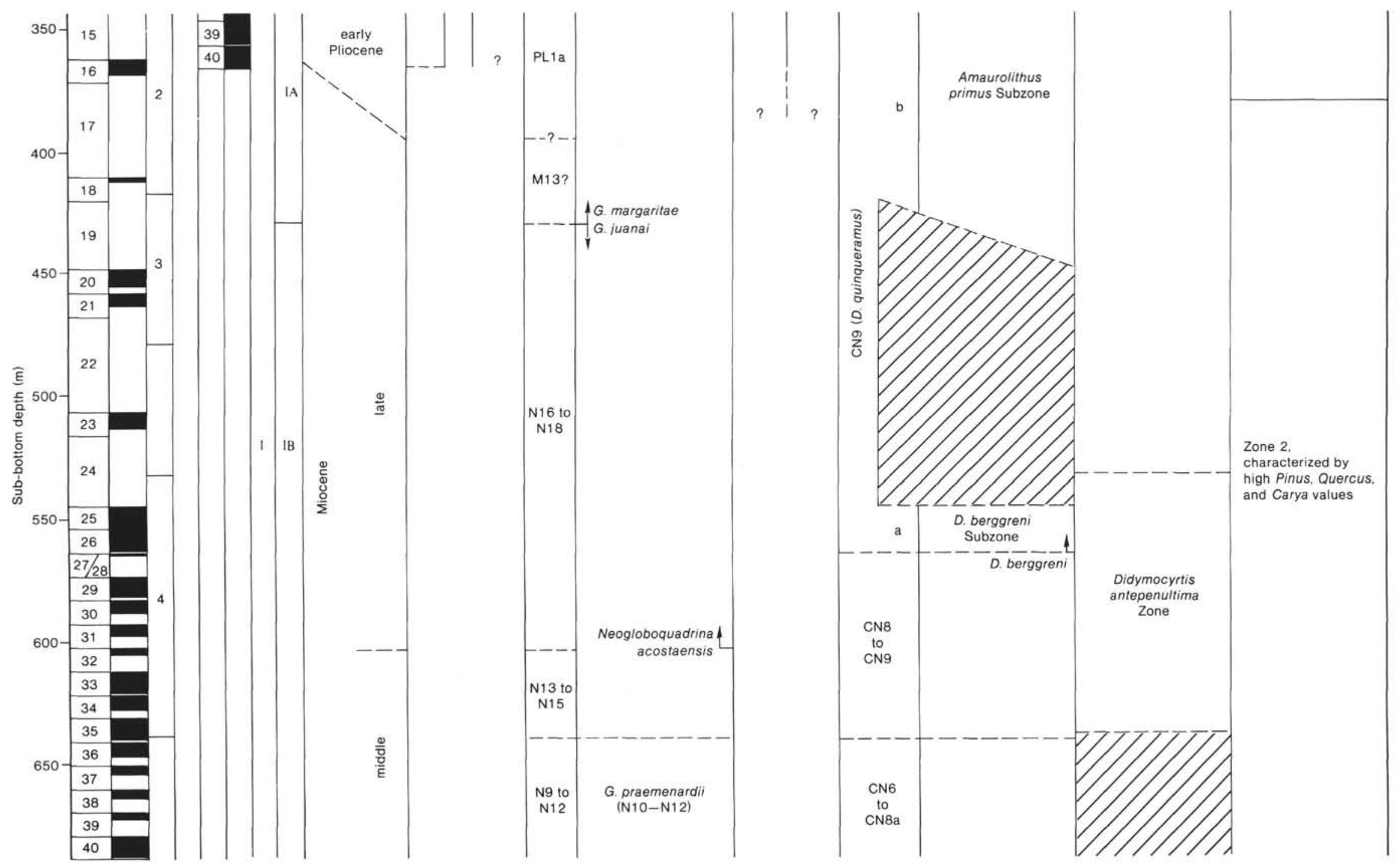

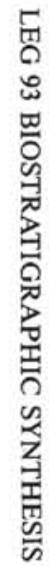

Figure 4. Cenozoic-Quaternary chronostratigraphy, magnetostratigraphy, and biostratigraphy, DSDP Site 603 . 


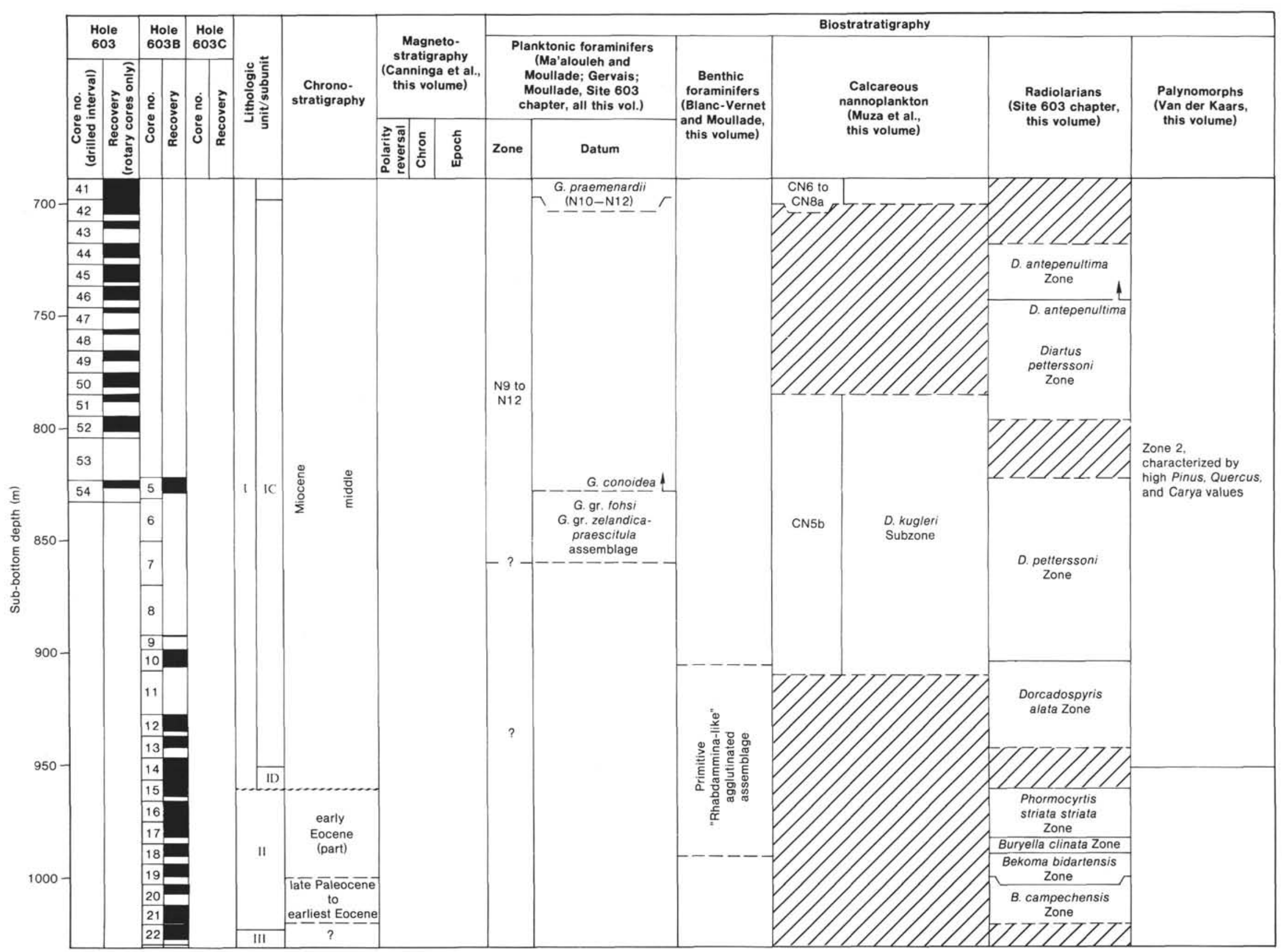


not reached in Hole 603C. The Miocene/Pliocene boundary, which is located in the middle of the reverse-polarity interval of Chron 3 (cf. Lowrie and Alvarez, 1981), should be somewhere in the interval between Cores $603 \mathrm{C}-37$ and -40 ( 330 to $365 \mathrm{~m}$ sub-bottom depth), that is, at least 20 $\mathrm{m}$ below the "nannofossil" boundary. The foraminiferal record does not help solve the problem. Berggren et al. (1983) have updated the Miocene part of the Blow (1969) zonation; in the new scheme a youngest Miocene zone (M13 = late Messinian) is defined by the co-occurrence of Globorotalia margaritae and Globoquadrina dehiscens. In Hole 603 the lowest occurrence of Globorotalia margaritae is in Core 19, at a sub-bottom depth of approximately $430 \mathrm{~m}$, but above this datum Globoquadrina dehiscens was not found because of severe calcite dissolution and/or climatic factors (Ma'alouleh and Moullade; Gervais; both this volume). As a result, the top of foraminiferal Zone M13, which also determines the Miocene/Pliocene boundary, cannot be identified at Site 603 .

The "nannofossil" Zanclean/Piacenzian (i.e., early/ late Pliocene) boundary coincides with the $\mathrm{CN} 11 / \mathrm{CN} 12$ zonal boundary (Okada and Bukry, 1980) and is found in Core 603C-21, at the same level as the "magnetostratigraphic" boundary (= Gilbert/Gauss limit; Lowrie and Alvarez, 1981). However, the "foraminiferal" boundary (PL2/PL3 zonal limit; Berggren et al, 1985) occurs $40 \mathrm{~m}$ below, in Core $603 \mathrm{C}-25$.

The Pliocene/Pleistocene boundary was until recently located at $1.85 \mathrm{Ma}$, in the lower third of the Olduvai normal-polarity Subchron (Chron 2). This boundary was biostratigraphically well defined, for it coincided with the first appearance of Globorotalia truncatulinoides (Haq et al., 1977). The last ICS Quaternary Subcommission resolution adopted at the 27th session of the International Geological Congress (Moscow, 1984) resulted in definition of a new Pliocene/Pleistocene boundary at $1.64 \mathrm{Ma}$, just above the top of the Olduvai Subchron (=1.67 Ma) (Aguirre and Pasini, 1985). For this report I have provisionally stayed with the previous determination, based on the FAD of $G$. truncatulinoides in Section 603C-5-2 (Ma'alouleh and Moullade, this volume). This datum corresponds to the top of the first third of the Olduvai Subchron, as depicted by Canninga et al. (this volume), and is located about $5 \mathrm{~m}$ below the highest occurence of Discoaster brouweri, which defines the upper limit of nannofossil Zone CN12.

\section{Site 604 (Fig. 5)}

On the basis of a relatively poor foraminiferal, nannofossil, and radiolarian record, Cores 604-23 (lowermost part) to $604-30$ and Cores $604 \mathrm{~A}-2$ to $604 \mathrm{~A}-5$ are given a late Miocene age. The presence of middle Miocene beds in the lowest part of Hole 604 cannot be biostratigraphically documented.

In Hole 604 the Miocene/Pliocene boundary is fixed just above the highest occurrence level of the planktonic foraminifer Globigerina praebulloides (Section 604-23-3), a cold-water species which, it is said, last appeared in the latest Miocene N18 Zone (sensu Kennett and Srinivasan, 1983). As at Site 603, climatic factors preclude the identification of the real last appearance level of the warm-water species Globoquadrina dehiscens (see Moullade, this volume) and thus the M13 Zone (sensu Berggren et al., 1983) cannot be strictly defined. The biostratigraphic resolution offered by the other microfossil groups at Site 604 is not sufficiently precise to solve this problem. The three CN10 nannofossil subzones have not been delineated in Hole 604, and a 12-m-thick interval devoid of significant markers separates upper Miocene beds (Core 604-26) from a lower Pliocene horizon (Cores 604-24 to -22) dated by radiolarians.

In Hole 604 the Pliocene/Pleistocene boundary is determined more on the basis of climatic rather than biostratigraphic arguments (Moullade, this volume). At such a latitude, the presence of most of the main (warm-water) foraminiferal markers appears to be highly dependent on temperature conditions. The first important cooling cycle noticed just above the uppermost Pliocene PL6 Zone coincides approximately with the lowest occurrence of Globorotalia truncatulinoides and both events enable us to place the Pliocene/Pleistocene boundary in Section 604-17-2 (Moullade, this volume; Ericson and Wollin, 1968).

The equivalents of all Ericson's climatic zones are defined in the Quaternary section of Hole 604, which seems to be sedimentarily complete, according to both the foraminiferal and nannofossil records.

\section{ACKNOWLEDGMENTS}

The author wishes to thank DSDP for inviting him to participate in Leg 93 of the Project. He also thanks Drs. Applegate, Blanc-Vernet, Bruins, Canninga, Covington, Gervais, Habib, Herbin, Lang, Ma'alouleh, Masure, Ogg, and Wise, who kindly communicated to him detailed information about their work and preprint versions of their manuscripts. Dr. Raynaud is specially acknowledged for having permitted the author to use unpublished data dealing with the Valanginian hypostratotype.

\section{REFERENCES}

Aguirre, E., and Pasini, G., 1985. The Pliocene-Pleistocene boundary. Episodes, 8(2):116-120.

Berggren, W. A., Aubry, M. P., and Hamilton, N., 1983. Neogene magnetobiostratigraphy of Deep Sea Drilling Project Site 516 (Rio Grande Rise, South Atlantic). In Barker, P. F., Carlson, R. L., Johnson, D. A., et al., Init. Repts. DSDP, 72: Washington (U.S. Govt. Printing Office), 675-713.

Berggren, W. A., Kent, D. V., Flynn, J. J. and Van Couvering, J. A., 1985. Cenozoic geochronology. Geol. Soc. Am. Bull., 96:1407-1418

Blow, W. H., 1969. Late middle Eocene to Recent planktonic foraminiferal biostratigraphy. In Brönnimann, P., and Renz, H. H. (Eds.), Proc. Ist. Int. Conf. Planktonic Microfossils, Geneva, 1967 (Vol. 1): Leiden (E. J. Brill), 199-421.

Busnardo, R., and Thieuloy, J. P., 1979. Les zones d'ammonites du Valanginien. In Busnardo, R., Thieuloy, J. P., and Moullade, M. (Eds.), Hypostratotype Mésogéen de l'Étage Valanginien (Sud-Est de la France), Editions du C.N.R.S., Les Stratotypes Français, 6: 58-68.

Busnardo, R., Thieuloy, J. P., and Moullade, M. (Eds.), 1979. Hypostratotype Mésogéen de l'Étage Valanginien (Sud-Est de la France), Editions du C.N.R.S., Les Stratotypes Français, 6.

Ericson, D. B., and Wollin, G., 1968. Pleistocene climates and chronology in deep sea sediments. Science, 162:1227-1234.

Gradstein, F. M., and Sheridan, R. E., 1983. On the Jurassic Atlantic Ocean and a synthesis of results of Deep Sea Drilling Project Leg 76. In Sheridan, R. E., Gradstein, F. M., et al., Init. Repts. DSDP, 76: Washington (U.S. Govt. Printing Office), 913-943.

Habib, D., and Drugg, W. S., 1983. Dinoflagellate age of Middle Jurassic-Early Cretaceous sediments in the Blake-Bahama Basin. In 
Sheridan, R. E., Gradstein, F. M., et al., Init. Repts. DSDP, 76: Washington (U.S. Govt. Printing Office), 623-638.

Haq, B. U., Berggren, W. A., and Van Couvering, J. A., 1977. Corrected age of the Pliocene/Pleistocene boundary. Nature, 269:483488.

Harland, W. B., Cox, A. V., Llewellyn, P. G., Pickton, C. A. G., Smith, A. G., and Walters, R. (Eds.), 1982. A Geologic Time Scale: Cambridge (Cambridge University Press).

Kennett, J. P., and Srinivasan, M. S., 1983. Neogene Plantonic Foraminifera. A Phylogenetic Atlas: Stroudsburg, PA (Hutchinson and Ross Publ. Co.).

Lowrie, W., and Alvarez, W., 1981. One hundred million years of geomagnetic polarity history. Geology, 9(9):392-397.

Manivit, H., 1979. Les nannofossiles. In Busnardo, R., Thieuloy, J. P., and Moullade, M. (Eds.), Hypostratotype Mésogéen de l'Étage Valanginien (Sud-Est de la France), Editions du C.N.R.S., Les Stratotypes Français, 6:87-98.

Moullade, M., 1966. Etude stratigraphique et micropaléontologique du Crétacé inférieur de la "fosse vocontienne". Doc, Lab. Geol. Fac. Sci. Lyon, 15:1-369.

1974. Zones de foraminifères du Crétacé inférieur mésogéen. C.R. Acad. Sci. Paris, Ser. D, 278:1813-1816.

1979. Foraminifères du Valanginien hypostratotypique. In Busnardo, R., Thieuloy, J. P., and Moullade, M. (Eds.), Hypostratotype Mésogéen de l'Étage Valanginien (Sud-Est de la France). Editions du C.N.R.S., Les Stratotypes Français, 6:110-126.

, 1984. Intérêt des petits foraminifères profonds pour la biostratigraphie et l'analyse des paléoenvironnements océaniques mé- sozoiques. II Internat. Symp. Benthic Foraminifera, Benthos 83, Pau, 1983, pp. 429-464.

Okada, H., and Bukry, D., 1980. Supplementary modification and introduction of code numbers to the low-latitude coccolith biostratigraphic zonation (Bukry, 1973; 1975). Mar. Micropaleontol., 5(3): $321-325$.

Perch-Nielsen, K., 1979. Calcareous nannofossils from the Cretaceous between the North Sea and the Mediterranean. In Wiedmann, J. (Ed.), Aspekte der Kreide Europas. Int. Union Geol. Sci. Ser. A, (Vol. 6): Stuttgart (Schweizerbart), pp. 223-272.

Renéville. P., de, and Raynaud, J. F., 1981. Palynologie du stratotype du Barrémien. Bull. Cen. Rech. Explor. -Prod. Elf-Aquitaine, 5(1): 1-29.

Roth, P. H., 1983. Jurassic and Lower Cretaceous calcareous nannofossils in the western North Atlantic (Site 534): biostratigraphy, perservation, and some observations on biogeography and paleoceanography. In Sheridan, R. E., Gradstein, F. M., et al., Init. Repts. DSDP, 76: Washington (U.S. Govt. Printing Office), 587-621.

Thierstein, H. R., 1971. Tentative Lower Cretaceous calcareous nannoplankton zonation. Eclogae Geol. Helv., 64:459-488. , 1976. Mesozoic calcareous nannoplankton biostratigraphy of marine sediments. Mar. Micropaleontol., 1:325-362.

Date of Initial Receipt: 7 August 1985

Date of Acceptance: 30 April 1986 
LEG 93 BIOSTRATIGRAPHIC SYNTHESIS

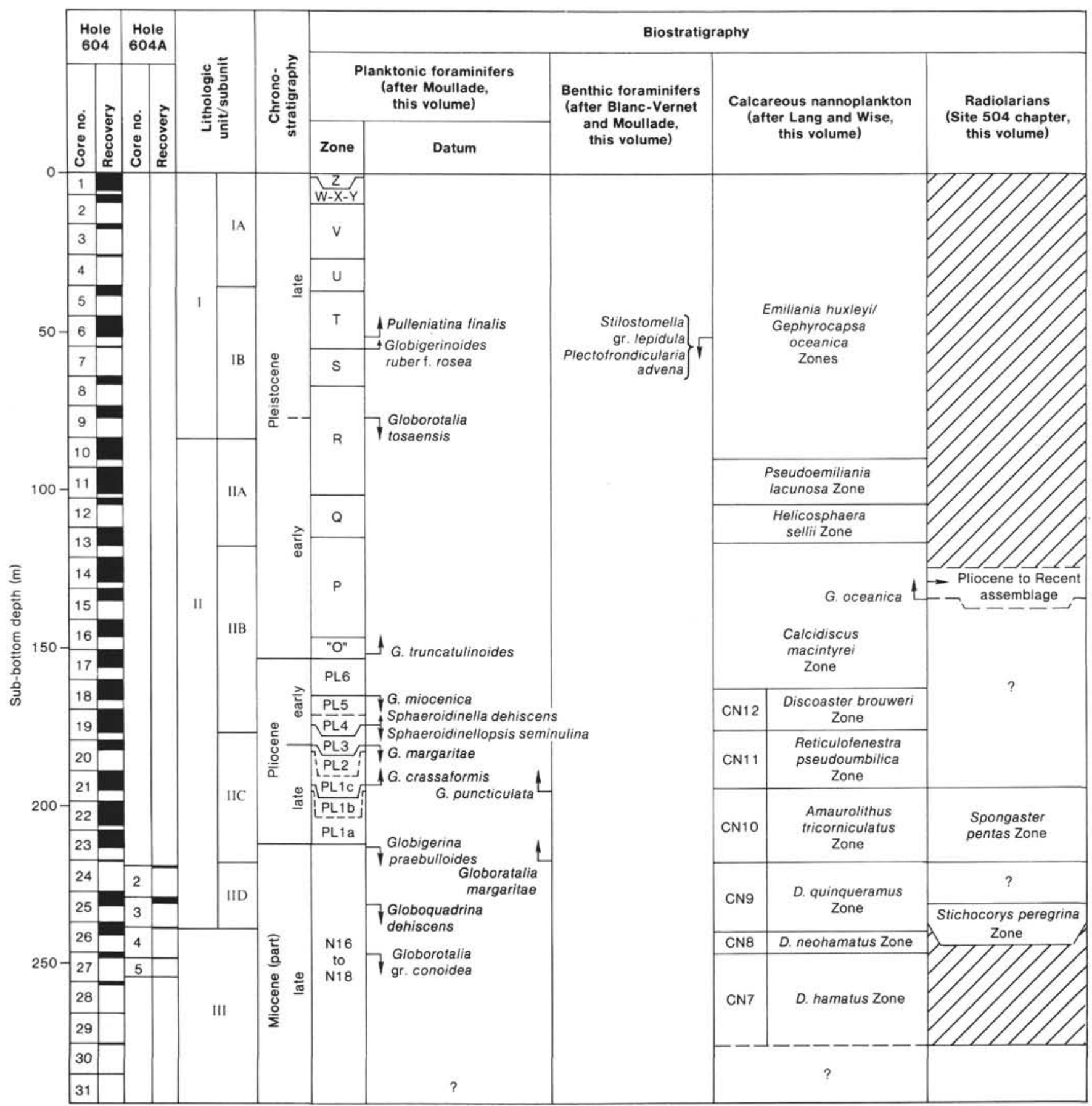

Figure 5. Neogene-Quaternary chronostratigraphy and biostratigraphy, DSDP Site 604. 